\title{
Research Article \\ Study on the Antinociceptive Effects of Herba Epimedium in Mice
}

\author{
Jiang-hong Sun, ${ }^{1}$ Xin-jie Ruan, ${ }^{2}$ Li-na Wang, ${ }^{1}$ Shuang Liang, ${ }^{1}$ and Xin-ping Li ${ }^{1}$ \\ ${ }^{1}$ Department of Animal Biotechnology, College of Veterinary Medicine, Northwest A \& F University, Yangling 712100, China \\ ${ }^{2}$ Henan Soar Veterinary Pharmaceutical Co., Ltd., Zhengzhou, Henan 45008, China \\ Correspondence should be addressed to Xin-ping Li; lixinping314159@163.com
}

Received 8 December 2014; Revised 20 April 2015; Accepted 21 April 2015

Academic Editor: Vincenzo De Feo

Copyright (c) 2015 Jiang-hong Sun et al. This is an open access article distributed under the Creative Commons Attribution License, which permits unrestricted use, distribution, and reproduction in any medium, provided the original work is properly cited.

\begin{abstract}
The present study was conducted to investigate the antinociceptive action of relationship between Herba Epimedium (HE) and 5- $\mathrm{HT}_{1 \mathrm{~A}}$ receptor, between Herba Epimedium (HE) and 5- $\mathrm{HT}_{2 \mathrm{~A}}$ receptor. We used the hot-plate method and the writhing assay in mice by the intracerebroventricular (i.c.v.) injection and observed the analgesic effect of HE. Furthermore, through the i.c.v. injection, 5- $\mathrm{HT}_{1 \mathrm{~A}}$ receptor partial agonist Buspirone, antagonist Propranolol, the adrenaline $\beta_{1}$-receptor selective blocking agent Metoprolol, and 5- $\mathrm{HT}_{2 \mathrm{~A}}$ receptor agonist hydrochloride DOI and antagonist Ketanserin were used, and, 5 min later, HE was used to investigate the impacts of drugs on the analgesic effect in the same way. Results showed that HE had fast and significant antinociception in nervous system, and the effects can persist for a long time. Buspirone and Hydrochloride DOI can remarkably increase the antinociception of HE in nervous system. Ketanserin leads to a significant decrease in its antinociception in nervous system; Metoprolol also has antinociceptive action in nervous system, but it can inhibit the antinociceptive effect of Herba Epimediumin peripheral region. These results suggest that HE has significant antinociception effect and its mechanism is related with $5-\mathrm{HT}_{1 \mathrm{~A}}$ receptor, $5-\mathrm{HT}_{2 \mathrm{~A}}$ receptor, and adrenaline $\beta_{1}$-receptor.
\end{abstract}

\section{Introduction}

The 5-hydroxytryptamine (5-HT) plays an important role in the nociceptive transmission. The involvement of central monoaminergic pathways in the antinociceptive mechanisms has been emphasized, and the role of serotonin (5-HT) in the modulation of the nociceptive stimuli has also been demonstrated $[1,2]$. The central serotonergic pathways have been claimed to exert antinociceptive effects in defined brain areas through their receptors, notably $5-\mathrm{HT}_{1 \mathrm{~A}}$ and $5-\mathrm{HT}_{2 \mathrm{~A}}$, as well as through interactions with opioid and $\gamma$-aminobutyric acid pathways [3-7].

Many previous studies have shown that activation of $5-\mathrm{HT}_{1 \mathrm{~A}}$ receptor can produce a strong analgesic effect [8-10] in the model of formalin-induced chronic pain, surgery, and postoperative pain of neuropathic pain models.

The distribution of $5-\mathrm{HT}_{2 \mathrm{~A}}$ receptor-labelled neurons in dorsal root ganglia (DRG) neurons is mainly small and medium-sized cells, which are nociceptive stimulation of primary sensory neurons. These cells mostly express both pain-related and calcitonin gene-related peptides [11]. The previous researches demonstrated that the antinociceptive effect of 5- $\mathrm{HT}_{2 \mathrm{~A}}$ receptor agonist Hydrochloride DOI in the formalin test is dose-dependent in rats [12].

Herba Epimedium (HE) is a family of plants consisting of Epimedium genera, and also is one of the most frequently used herbs in formulas for the treatment of lots of diseases in China. Modern medical researches have showed that HE contains flavonoid compounds and has the antinociceptive effect [13]. HE has the analgesic effect, but there are few researches about it and the detailed mechanisms underlying the analgesic effects of it are still unclear. In the present study, we investigated the mechanism of its analgesic effect using the hot-plate test and the writhing assay, by i.c.v. injections of 5- $\mathrm{HT}_{1 \mathrm{~A}}$ receptor, 5- $\mathrm{HT}_{2 \mathrm{~A}}$ receptor agonists, and antagonists, 
with the aim to reveal the relationship of analgesic effect between $\mathrm{HE}$ and the 5-HT receptors.

\section{Materials and Methods}

2.1. Animals. Adult female Kunming mice were obtained from Animal Center of Medicine Department in Xi'an Jiaotong University. All mice were housed in standard cages and maintained on a 12:12 h light/dark cycle under conditions of constant $23^{\circ} \mathrm{C}$ ambient temperature. The mice were given a free access to food and water. After one-week acclimatization, these mice were assigned randomly into a group fed with standard mice chow $(n=8$, weight: $18-22 \mathrm{~g})$.

2.2. Drugs. Herba Epimedium (Epimedium enshiense B. L. Guo et $\mathrm{Hsiao}$ ), the $5-\mathrm{HT}_{1 \mathrm{~A}}$ receptor partial agonist Buspirone, the beta-noradrenergic receptors nonselective antagonist propranolol, the $\beta_{1}$-adrenergic selective antagonist metoprolol, and the $5-\mathrm{HT}_{2 \mathrm{~A}}$ receptor preferential antagonist Ketanserin were purchased from Research Biochemicals. The $5-\mathrm{HT}_{2 \mathrm{~A}}$ receptor selective agonist DOI-Hydrochloride was purchased from Sigma.

2.3. Drug Treated Groups. In this study, the mice were divided into the control group, of which each group was treated with i.c.v. injection of saline solution $(2 \mu \mathrm{m} / \mathrm{L})$, the $\mathrm{HE}+$ Metoprolol group, of which the mice were treated with Herba Epimedium (1:4), the $\beta_{1}$-adrenergic selective antagonist Metoprolol $(2 \mu \mathrm{m} / \mathrm{L})$, and Herba Epimedium, respectively, and four separate groups of mice were treated with the $5-\mathrm{HT}_{1 \mathrm{~A}}$ receptor partical agonist Buspirone $(2 \mu \mathrm{m} / \mathrm{L})$, the beta-noradrenergic receptors nonselective antagonist propranolol $(2 \mu \mathrm{m} / \mathrm{L})$, the $5-\mathrm{HT}_{2 \mathrm{~A}}$ receptor preferential antagonist Ketanserin $(1 \mu \mathrm{m} / \mathrm{L})$, and the $5-\mathrm{HT}_{2 \mathrm{~A}}$ receptor selective agonist DOI-Hydrochloride $(1 \mu \mathrm{m} / \mathrm{L})$, respectively, administered 5 min after Herba Epimedium (1:4) administration.

2.4. Preparation of Aqueous Extract of Epimedium. Herba Epimedium ( $100 \mathrm{~g}$ ) were soaked in (how much) $\mathrm{mL}$ of distilled water for an hour and then boiled three times, every time for $30 \mathrm{~min}$. Then the filtration was combined, and the first extraction was concentrated to $200 \mathrm{~mL}$ by simmering and then was extracted with $200 \mathrm{~mL}$ of $95 \%$ ethanol for 3 times and placed at $4^{\circ} \mathrm{C}$ or $-20^{\circ} \mathrm{C}$ overnight. The compound was filtered. After filtration, each residual was discarded and the final filtrates were concentrated under vacuum to eliminate solvent and double distilled water was added into the extract to the final volume of $10 \mathrm{~mL} .2 \% \mathrm{NaOH}$ was used to adjust the $\mathrm{pH}$ to 7.0. The concentration of the herbal soup is equivalent to crude herb of $1 \mathrm{~g} / \mathrm{mL}$, kept in refrigerator.

2.5. Drugs Administration and i.c.v. Injection. The 5-HT receptors agonists and antagonists were dissolved in sterile $0.9 \% \mathrm{NaCl}$ as vehicle containing $0.1 \%$ Evans Blue dye. This saline solution was used as a vehicle and the control treatment. i.c.v. injection was performed according to a method reported previously $[14,15]$. The needle was placed vertically on the head, the needle was lightly forward to locate bregma, and the needle position was $1 \mathrm{~mm}$ posterior and $1 \mathrm{~mm}$ lateral to the bregma. Herbal solutions were infused slowly (over $30 \mathrm{~s}$ ) into the lateral ventricle and injected i.c.v. in a volume of $10 \mu \mathrm{L}$. At the end of each experiment, the mice were sacrificed by injection of an overdose of urethane. Then the brain was removed to confirm the accuracy of injection. The data from brains which confirmed having Evans Blue dye present in the lateral ventricle were used.

2.6. Hot-Plate Test. In this test, animals were individually placed on a hot plate with constant temperature (55 \pm $0.5^{\circ} \mathrm{C}$ ) [16]. The latencies to first hind paw withdrawal during thermal stimulation were measured in seconds as indexes of nociceptive threshold with cut-off time of 50-second reaction times were measured with a stopwatch and each of the mice was tested before treatment and 5, 15, and $30 \mathrm{~min}$ after treatment. Those mice scores below $10 \mathrm{~s}$ or over $60 \mathrm{~s}$ in the pretest were rejected, after which the animals were immediately removed from the hot plate.

2.7. Writhing Test. The writhing test described by Hayashi and Takemori [17] was used to assess the analgesia effect. Mice were i.c.v. injected with $2 \%$ acetic acid in order to produce the typical writhing reaction, which is characterized by a wave of contraction of the abdominal musculature followed by extension of the hind limbs. The mice were then placed in an individual container and the number of writhes in 35 min was counted, starting from $5 \mathrm{~min}$ after acetic acid administration.

2.8. Statistical Analysis. Data from experiments were statistically analyzed with one-way analysis of variance (ANOVA) and $t$-test. With respect to treatment and time, the KruskalWallis test was used. Data are expressed as means \pm SEM. Statistical significance was set at $P<0.05$ for all experiments.

\section{Results}

3.1. The Pain Threshold in Hot-Plate Test of HE + Metoprolol Groups. The i.c.v. administration of $\mathrm{HE}$ and Metoprolol potently increased the pain threshold $30 \mathrm{~min}$ after injection in the mouse hot plate. Antinociception of the Herba Epimedium group reached the maximum after $15 \mathrm{~min}$, and the Metoprolol ( $2 \mu \mathrm{mol}$ per mouse) reached the maximum after $5 \mathrm{~min}$. Both of them can persist for up to $30 \mathrm{~min}$. The mice having received i.c.v. HE and Metoprolol exhibited significant antinociception. There was no significant difference in the increase in pain threshold following i.c.v. injection between the HE group and Metoprolol group $(P>0.05)$ (Figure 1).

3.2. The Antinociceptive Effect of $H E$ and Metoprolol on the Abdominal Constriction Test. The antinociceptive effects of Herba Epimedium and Metoprolol on the abdominal constriction test were illustrated in Figure 2. The abdominal constriction test was performed $35 \mathrm{~min}$ after i.c.v. administration. The writhing times of mouse were significantly decreased by the $\mathrm{HE}(P<0.01)$ and persisted for up to $35 \mathrm{~min}(P<0.05)$, but the effect of Metoprolol was different 


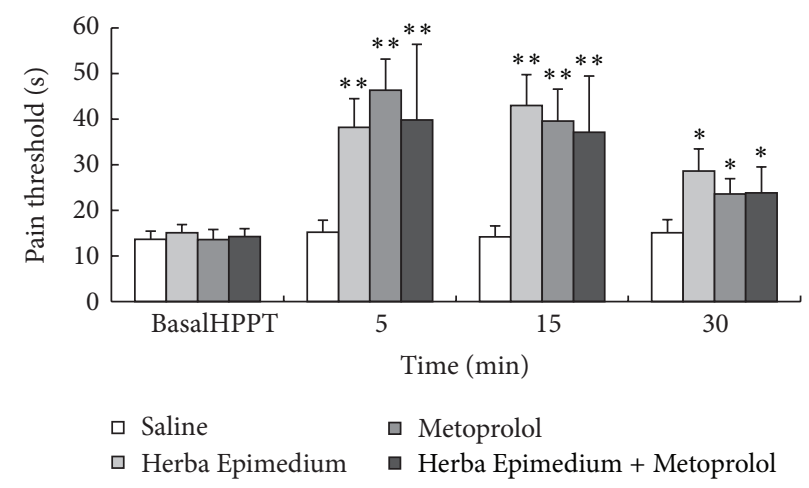

Figure 1: The pain threshold in hot-plate test during $30 \mathrm{~min}$ after i.c.v. injection of Herba Epimedium and Metoprolol. Values are means \pm S.E.M. Significant difference from the control (saline) at each time point represented ${ }^{* *} P<0.01$ and ${ }^{*} P<0.05$.

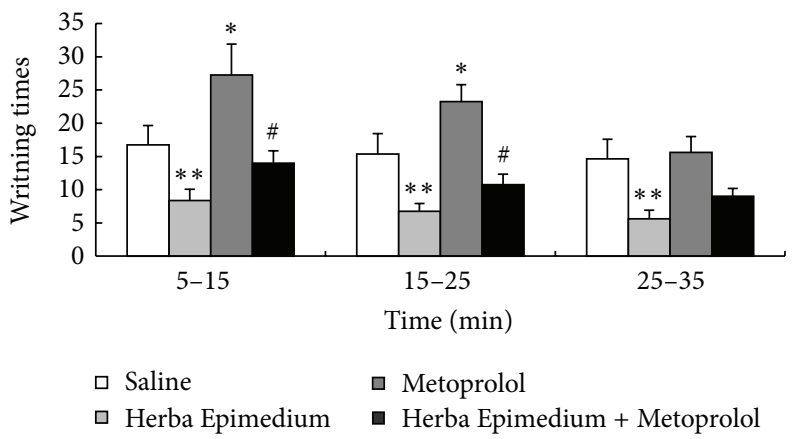

FIGURE 2: The writhing times in the mouse acetic acid abdominal constriction test during 35 min after i.c.v. injection of HE and Metoprolol. Values are means \pm S.E.M. Significant difference from the control (saline) at each time point represented ${ }^{* *} P<0.01$ and ${ }^{*} P<0.05$. ${ }^{\sharp} P<0.05$ compared to HE.

from those in the hot-plate test. It had no antinociceptive effect compared to the vehicle group. The writhing times were significantly increased during $25 \mathrm{~min}$ after the administration $\left({ }^{*} P<0.05\right)$. Posttreatment after $35 \mathrm{~min}$ had no significant difference from the control group. Whereas the writhing time was significantly decreased after injection of $\mathrm{HE}$ and Metoprolol compared to the Metoprolol group during $25 \mathrm{~min}$ after the administration $\left({ }^{\#} P<0.05\right)$, the magnitude of the three phase did not differ significantly from the Metoprolol group.

3.3. The Effect of i.c.v. Injection of HE, Buspirone, and Propranolol. The effect of i.c.v. injection of HE, Buspirone, and Propranolol on $30 \mathrm{~min}$ pain threshold value was shown in Figure 3. In the hot-plate test, HE strongly increased the pain threshold value and persisted for up to $30 \mathrm{~min}$ $\left({ }^{\mathrm{a}} \mathrm{P}<0.01\right) ; 5-\mathrm{HT}_{1 \mathrm{~A}}$ receptor partial agonist Buspirone can increase the antinociceptive effect of $\mathrm{HE} 15 \mathrm{~min}$ after injection $\left({ }^{b} P<0.05\right)$. However, the antagonist Propranolol significantly decreased the antinociception of $\mathrm{HE}$ through 30 min after injection $\left({ }^{c} P<0.01\right)$.

3.4. The Effect of 5-HT ${ }_{2 A}$ Receptor Agonist ( \pm )-DOI Hydrochloride and Antagonist Ketanserin. The i.c.v. administration of $5-\mathrm{HT}_{2 \mathrm{~A}}$ receptor agonist $( \pm)$-DOI Hydrochloride increases the antinociceptive effect of $\mathrm{HE}$ at $15 \mathrm{~min}$ and $30 \mathrm{~min}\left({ }^{\mathrm{b}} \mathrm{P}<\right.$ 0.05 ) in the hot-plate test, but the $5-\mathrm{HT}_{2 \mathrm{~A}}$ receptor antagonist Ketanserin inhibited the antinociception of $\mathrm{HE}$ at $30 \mathrm{~min}$ after injection $\left({ }^{\mathrm{c}} \mathrm{P}<0.01\right)$ (Figure 4 ).

3.5. The Antinociception of HE, Propranolol, and Buspirone in the Acetic Acid Abdominal Constriction Test. This experiment indicated that the $5-\mathrm{HT}_{1 \mathrm{~A}}$ receptor antagonist Propranolol can increase the writhing times in the test compared to the control group and the magnitude of inhibitory effect was similar to that experiment of hot plate. $5-\mathrm{HT}_{1 \mathrm{~A}}$ receptor partial agonist Buspirone can also increase the antinociception of $\mathrm{HE}$ in the acetic acid abdominal constriction test. The writhing times significantly decreased compared with the HE group $\left({ }^{b} P<0.05\right)$ (Figure 5).

3.6. The Antinociceptive Effects of Hydrochloride DOI and Ketanserin in the Acetic Acid Abdominal Constriction Test. The abdominal constriction test was performed $35 \mathrm{~min}$ after i.c.v. administration. The test indicated that $5-\mathrm{HT}_{2 \mathrm{~A}}$ receptor antagonist Ketanserin could suppress the antinociception of $\mathrm{HE}$; the writhing times of mouse were significantly increased at $35 \mathrm{~min}$ after injection, compared to the HE group $\left({ }^{\mathrm{a}} \mathrm{P}<\right.$ $0.05) .5-\mathrm{HT}_{2 \mathrm{~A}}$ receptor agonist $( \pm)$-DOI Hydrochloride could 


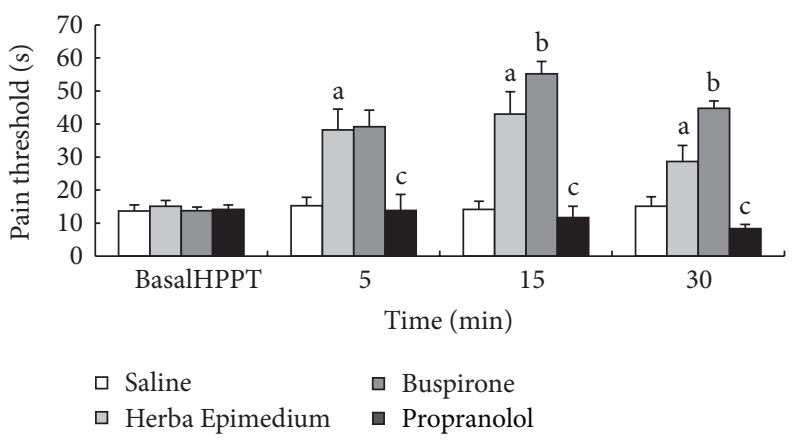

FIGURE 3: Pain threshold in hot-plate test during $30 \mathrm{~min}$ after i.c.v. injection of HE, Buspirone, and Propranolol. Values are means \pm S.E.M. ${ }^{\mathrm{a}} \mathrm{P}<0.01$ compared to corresponding control group. ${ }^{\mathrm{b}} \mathrm{P}<0.05,{ }^{\mathrm{c}} \mathrm{P}<0.01$ compared to corresponding Herba Epimedium group.

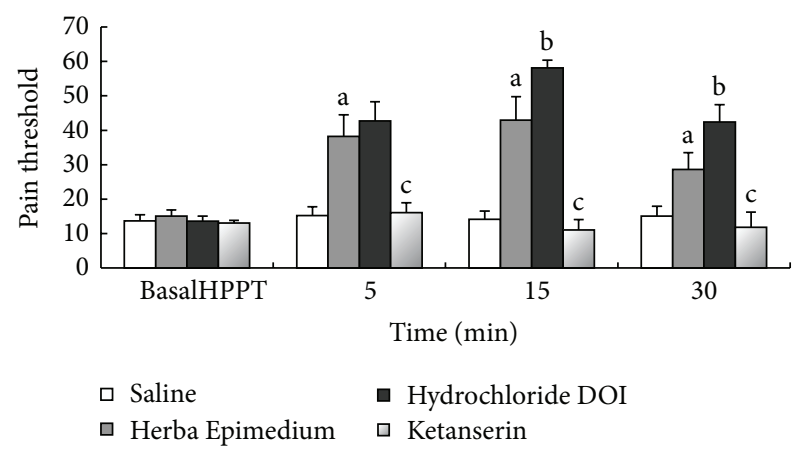

FIGURE 4: Pain threshold in hot-plate test during 30 min after i.c.v. injection of HE, Hydrochloride DOI, and Ketanserin. Values are means \pm S.E.M. ${ }^{\mathrm{a}} P<0.01$ compared to corresponding control group. ${ }^{\mathrm{b}} \mathrm{P}<0.05,{ }^{\mathrm{c}} \mathrm{P}<0.01$ compared to corresponding HE group.

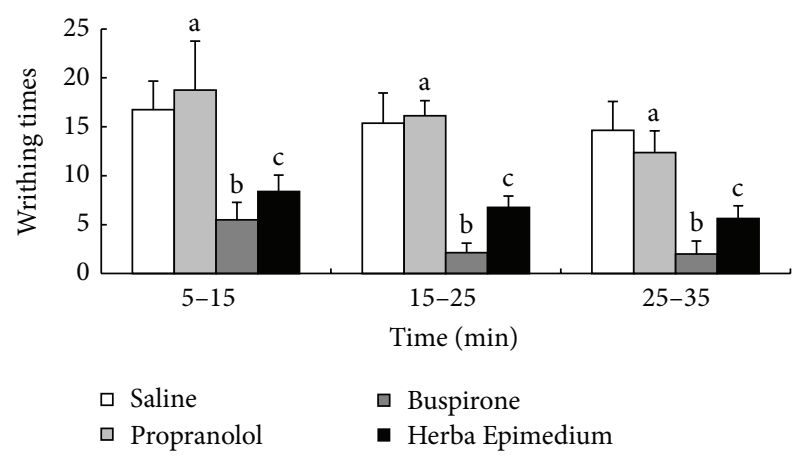

FIgURE 5: The writhing times in the mouse acetic acid abdominal constriction test during $35 \mathrm{~min}$ after i.c.v. injection of HE, Propranolol, and Buspirone. Values are means \pm S.E.M. ${ }^{\mathrm{a}} P<0.01$, ${ }^{\mathrm{b}} P<0.05$ compared to corresponding Herba Epimedium group. ${ }^{\mathrm{c}} P<0.01$ compared to corresponding control group.

increase the antinociceptive effect of $\mathrm{HE}$ and the writhing times decreased 35 min after injection $\left({ }^{\mathrm{b}} P<0.05\right)$ (Figure 6).

\section{Discussions}

Herba Epimedium, which contains several medically active constituents including flavonoids and phytosteroids, has been

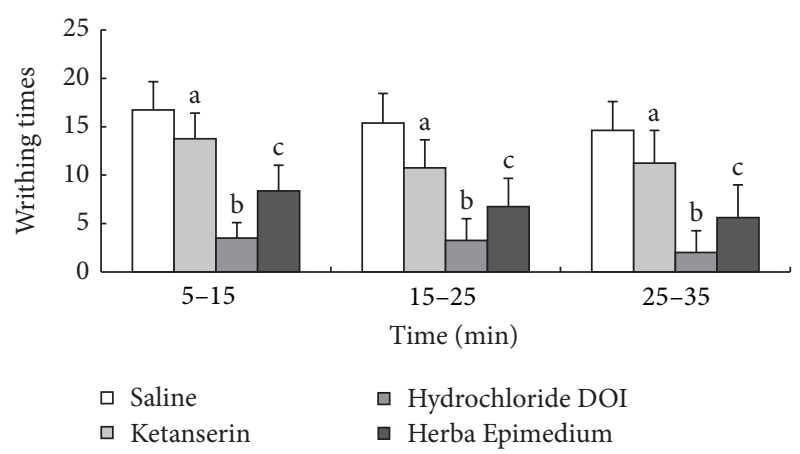

FIgURE 6: The writhing times in the mouse acetic acid abdominal constriction test during $35 \mathrm{~min}$ after i.c.v. injection of HE, Hydrochloride DOI, and Ketanserin. Values are means \pm S.E.M. ${ }^{\mathrm{a}} P<0.05,{ }^{\mathrm{b}} \mathrm{P}<0.05$ compared to corresponding HE group. ${ }^{\mathrm{c}} \mathrm{P}<$ 0.01 compared to corresponding control group.

widely used in China in the treatment of cardiovascular diseases, infertility, impotence, amnesia, lumbago, arthritis, numbness, and weakness of the limbs for thousands of years $[18,19]$. Recently, several studies have shown that the crude extract, total flavonoids, and main flavonoid constituents from Herba Epimedium had the antinociception effect [13, 20]. In our study, the Herba epimedium significantly elevated the pain threshold in the mouse hot-plate (Figure 1) and abdominal constriction (Figure 2) tests. Total flavonoids and main flavonoid constituents had the antinociceptive effect [21]. However, the mechanism of antinociception of Herba Epimedium aqueous extract which contained flavonoid was not clear. Adrenaline $\beta_{1}$-receptor selective blocking agent has sedative, analgesic, and anxiolytic effects by blocking the central $\beta$ receptor [22]. In the present study, Metoprolol showed opposite effects between the hot-plate tests (Figure 1). And in abdominal constriction test (Figure 2), Metoprolol has the significant antinociception in the central nervous system, but has the role of pain in peripheral region. It was possible that Metoprolol only had the antinociceptive effect in central nervous system. The increase of pain threshold was also detected by injection of both Metoprolol and Herba Epimedium, the results indicated that Herba Epimedium had the inhibitory effect to the Metoprolol, especially in the abdominal 
constriction test, and the writhing times of mouse were significantly decreased $35 \mathrm{~min}$ after injection $(P<0.01)$ in the present study. In vitro and animal experiment had proved that total flavones of Herba Epimedium have the selective block effect on adrenergic $\beta_{1}$ receptor [23].

5 -HT is an endogenous bioactive substance released from platelets and mast cells in injured or inflamed tissues. Endogenous or exogenous 5-HT causes noxious and hyperalgesic reactions in peripheral tissues in human and animals. Intracutaneous injection of platelets causes acute pain and hyperalgesia in human [24], it was reported that subtly 5-HT receptors were involved in 5-HT induced pain and hyperalgesia. So many selective drugs have been allowed to develop for treating inflammatory pain and hyperalgesia. Bianchi et al. [25] demonstrated that the full $5-\mathrm{HT}_{1 \mathrm{~A}}$ agonist $8-\mathrm{OH}-\mathrm{DPAT}$ was able to increase ACh release from the cerebral cortex of freely moving guinea pigs. $5-\mathrm{HT}_{1 \mathrm{~A}}$ receptor partial agonist Buspirone was able to induce antinociception in mice; the increased pain threshold was detected by using both thermal (hot-plate test) and chemical stimuli (abdominal constriction test) [26]. In the present study, the result indicated that Buspirone can significantly increase the antinociceptive effect of Herba Epimedium; it was possible that analgesic of Herba Epimedium was related to the $5-\mathrm{HT}_{1 \mathrm{~A}}$ receptor. The antinociception of Herba Epimedium was suppressed by the antagonist Propranolol.

It is well known that 5 -HT is involved in many complex effects on pain and hyperalgesia through various subtype of receptors located at various levels of the pain transmission system. In a previous experiment, the intraperitoneal administration of acetic acid formalin evoked extremely long-lasting inhibition of somatic inflammatory pain in mice. The study indicated that long-lasting antinociception was completely blocked by the $5-\mathrm{HT}_{2 \mathrm{~A}}$ receptor antagonists, Ketanserin [27]. Peiró et al. reported 5-HT inhibition of the kappa-opioid component of morphine antinociceptive effects and the possibility that this serotonergic inhibition could be reversed through 5-HT2 receptor antagonist Ketanserin [28]. Crisp et al. reported that intrathecal administration of 5-HT agonist, 8-OH-DPAT produced hyperalgesia with the tailflick test and analgesia with the hot-plate test, and $5-\mathrm{HT}_{1 \mathrm{~B}}$ agonist, TFMPP, 5- $\mathrm{HT}_{2 \mathrm{~A}}$ agonist and DOI phenylbiguanide produced analgesia with the hot-plate test in the rat [29]. Therefore, the 5-HT receptor agonists or antagonists may act and change the pain-related behavior. In this study, the i.c.v. administration of $5-\mathrm{HT}_{2 \mathrm{~A}}$ receptor agonist $( \pm)$ DOI Hydrochloride can increase the antinociceptive effect of Herba Epimedium at $15 \mathrm{~min}$ and $30 \mathrm{~min}(P<0.05)$ in the hot-plate test, but the $5-\mathrm{HT}_{2 \mathrm{~A}}$ receptor antagonist Ketanserin inhibited the antinociception of Herba Epimedium through 30 min after injection $(P<0.01)$. As reported previously [30], the Ketanserin has a nonselective action, also exerting some effects on alpha-1-noradrenergic receptors.

In the acetic acid abdominal constriction test, the study indicated that $5-\mathrm{HT}_{2 \mathrm{~A}}$ receptor antagonist Ketanserin could suppress the antinociception of Herba Epimedium. The writhing times of mouse were significantly increased through 35 min after injection, which compared to the Herba Epimedium group $\left({ }^{\mathrm{a}} \mathrm{P}<0.05\right) .5-\mathrm{HT}_{2 \mathrm{~A}}$ receptor agonist
$( \pm)$-DOI Hydrochloride could increase the antinociceptive effect of Herba Epimedium and the writhing times decreased during the $35 \mathrm{~min}\left({ }^{\mathrm{b}} \mathrm{P}<0.05\right)$. Therefore, the hyperalgesia induced by the hot-plate test and acetic acid test was inhibited by Herba Epimedium, and the antinociception of Herba Epimedium was mediated via the $5-\mathrm{HT}_{2 \mathrm{~A}}$ receptor agonist and antagonist.

Several evidences indicated that $5-\mathrm{HT}_{1 \mathrm{~A}}$ and $5-\mathrm{HT}_{2 \mathrm{~A}}$ receptor subtype contributed to antinociception. Moreover, Herba Epimedium has the antinociceptive effect in central nervous system and peripheral region $[13,20]$. At the moment, we speculate that the antinociception of Herba Epimedium was mediated by the agonist and antagonist of $5-\mathrm{HT}_{1 \mathrm{~A}}$ receptor and $5-\mathrm{HT}_{2 \mathrm{~A}}$ receptor, but the mediating mechanisms are not clear; further studies are necessary to characterize this pain facilitatory mechanism.

\section{Conclusions}

From all above experiments, we concluded that HE had significant antinociceptive effect and the mechanism of its antinociception was connected with $5-\mathrm{HT}_{1 \mathrm{~A}}$ receptor, $5-\mathrm{HT}_{2 \mathrm{~A}}$ receptor, and adrenaline $\beta_{1}$-receptor.

\section{Conflict of Interests}

The authors declare that there is no conflict of interests regarding the publication of this paper.

\section{References}

[1] T. Pelissier, A. Alloui, C. Paeile, and A. Eschalier, "Evidence of a central antinociceptive effect of paracetamol involving spinal 5- $\mathrm{HT}_{3}$ receptors," Neuroreport, vol. 6, no. 11, p. 1546, 1995.

[2] L. A. Pini, M. Sandrini, and G. Vitale, "Involvement of brain serotonergic system in the antinociceptive action of acetylsalicylic acid in the rat," Inflammation Research, vol. 44, no. 1, pp. 30-35, 1995.

[3] P. K. Eide and K. Hole, "Different role of 5-HT $1 \mathrm{~A}$ and 5$\mathrm{HT}_{2}$ receptors in spinal cord in the control of nociceptive responsiveness," Neuropharmacology, vol. 30, no. 7, pp. 727-731, 1991.

[4] A. A. Alhaider, "Antinociceptive effect of ketanserin in mice: involvement of supraspinal $5-\mathrm{HT}_{2}$ receptors in nociceptive transmission," Brain Research, vol. 543, no. 2, pp. 335-340, 1991.

[5] S. T. Meller, S. J. Lewis, M. J. Brody, and G. F. Gebhart, "The peripheral nociceptive actions of intravenously administered 5$\mathrm{HT}$ in the rat requires dual activation of both $5-\mathrm{HT}_{2}$ and 5$\mathrm{HT}_{3}$ receptor subtypes," Brain Research, vol. 561, no. 1, pp. 61-68, 1991.

[6] D. S. Nichols, B. E. Thorn, and G. G. Berntson, "Opiate and serotonergic mechanisms of stimulation-produced analgesia within the periaqueductal gray," Brain Research Bulletin, vol. 22, no. 4, pp. 717-724, 1989.

[7] G. Tunnicliff, "Significance of $\gamma$-hydroxybutyric acid in the brain," General Pharmacology, vol. 23, no. 6, pp. 1027-1034, 1992.

[8] L. Bardin, J. P. Tarayre, N. Malfetes, W. Koek, and F. C. Colpaert, "Profound, non-opioid analgesia produced by the high-efficacy 5- $\mathrm{HT}_{1 \mathrm{~A}}$ agonist $\mathrm{F} 13640$ in the formalin model of 
tonic nociceptive pain," Pharmacology, vol. 67, no. 4, pp. 182194, 2003.

[9] I. Kiss, A.-D. Degryse, L. Bardin, I. A. G. de Segura, and F. C. Colpaert, "The novel analgesic, F 13640, produces intraand postoperative analgesia in a rat model of surgical pain," European Journal of Pharmacology, vol. 523, no. 1-3, pp. 29-39, 2005.

[10] K. Deseure, S. Bréand, and F. C. Colpaert, "Curative-like analgesia in a neuropathic pain model: parametric analysis of the dose and the duration of treatment with a high-efficacy 5$\mathrm{HT}_{1 \mathrm{~A}}$ receptor agonist," European Journal of Pharmacology, vol. 568, no. 1-3, pp. 134-141, 2007.

[11] K. Okamoto, H. Imbe, Y. Morikawa et al., "5-HT2A receptor subtype in the peripheral branch of sensory fibers is involved in the potentiation of inflammatory pain in rats," Pain, vol. 99, no. 1-2, pp. 133-143, 2002.

[12] M. Sasaki, K. Ishizaki, H. Obata, and F. Goto, "Effects of 5HT2 and 5-HT3 receptors on the modulation of nociceptive transmission in rat spinal cord according to the formalin test," European Journal of Pharmacology, vol. 424, no. 1, pp. 45-52, 2001.

[13] L. Li, J. Zeng, Z. Huang, Z. Li, and Q. Zhou, "A study of the anlgesic effect of Herba epimedium extract," Journal of Gannan Medical College, no. 1, pp. 14-15, 2004.

[14] R. W. Horton, J. F. Collins, G. M. Anlezark, and B. S. Meldrum, "Convulsant and anticonvulsant actions in DBA/2 mice of compounds blocking the reuptake of GABA," European Journal of Pharmacology, vol. 59, no. 1-2, pp. 75-83, 1979.

[15] H. C. Jackson and M. A. Scheideler, "Behavioural and anticonvulsant effects of $\mathrm{Ca}^{2+}$ channel toxins in DBA/2 mice," Psychopharmacology, vol. 126, no. 1, pp. 85-90, 1996.

[16] J. P. O'Callaghan and S. G. Holtzman, "Quantification of the analgesic activity of narcotic antagonists by a modified hotplate procedure," Journal of Pharmacology and Experimental Therapeutics, vol. 192, no. 3, pp. 497-505, 1975.

[17] G. Hayashi and A. E. Takemori, "The type of analgesic-receptor interaction involved in certain analgesic assays," European Journal of Pharmacology, vol. 16, no. 1, pp. 63-66, 1971.

[18] Chinese Pharmacopoeia Commission, "Herba epimedii," in Chinese Pharmacopoeia, Part I, Chinese Pharmacopoeia Commission, Ed., p. 229, Chemical Industry Press, Beijing, China, 2005.

[19] H. C. Yeung, Handbook of Chinese Herbs and Formulas, Institute of Chinese Medicine, Los Angeles, Calif, USA, 1985.

[20] Y. Qing, Y. Zhu, and L. Zhu, "Anagesic effect and acute toxicity studies of Herba Epimedium Capsule compounds in mice," Jounal of SuZhou University, vol. 28, no. 4, 2008.

[21] L. Zhang, C. Zhao, Z. Chen et al., "The mechanism of anticiceptive effect with the Ginkgo Bioba flavonoids," Jounal of An Hui Medicine Univercity, vol. 36, no. 4, p. 263, 2001.

[22] M. Coloma, J. W. Chiu, P. F. White, and S. C. Armbruster, "The use of esmolol as an alternative to remifentanil during desflurane anesthesia for fast-track outpatient gynecologic laparoscopic surgery," Anesthesia and Analgesia, vol. 92, no. 2, pp. 352-357, 2001.

[23] L.-Z. Xu and W.-N. Chen, "Blocking effect of total flavones of epimedium on adrenergic receptor," Chinese Pharmacological Bulletin, vol. 10, no. 4, pp. 311-314, 1994.

[24] M. Schmelz, G. Osiander, J. Blunk, M. Ringkamp, P. W. Reeh, and H. O. Handwerker, "Intracutaneous injections of platelets cause acute pain and protracted hyperalgesia," Neuroscience Letters, vol. 226, no. 3, pp. 171-174, 1997.
[25] C. Bianchi, A. Siniscalchi, and L. Beani, "5-HT $1 \mathrm{~A}$ agonists increase and $5-\mathrm{HT}_{3}$ agonists decrease acetylcholine efflux from the cerebral cortex of freely-moving guinea-pigs," British Journal of Pharmacology, vol. 101, no. 2, pp. 448-452, 1990.

[26] N. Galeotti, C. Ghelardini, and A. Bartolini, "5-HT(1A) agonists induce central cholinergic antinociception," Pharmacology Biochemistry and Behavior, vol. 57, no. 4, pp. 835-841, 1997.

[27] T. Kurihara, T. Nonaka, and T. Tanabe, "Acetic acid conditioning stimulus induces long-lasting antinociception of somatic inflammatory pain," Pharmacology Biochemistry and Behavior, vol. 74, no. 4, pp. 841-849, 2003.

[28] A. M. Peiró, L. Climent, P. Zapater, A. Horga, and J. F. Horga, "Ketanserin potentiates morphine-induced antinociception mediated by kappa-receptor activation," Pharmacological Research, vol. 64, no. 1, pp. 80-84, 2011.

[29] T. Crisp, J. L. Stafinsky, L. J. Spanos, M. Uram, V. C. Perni, and H. B. Donepudi, "Analgesic effects of serotonin and receptorselective serotonin agonists in the rat spinal cord," General Pharmacology, vol. 22, no. 2, pp. 247-251, 1991.

[30] M. Israilova, F. Suzuki, T. Tanaka, T. Nagatomo, T. Taniguchi, and I. Muramatsu, "Binding and functional affinity of sarpogrelate, its metabolite M-1 and ketanserin for human recombinant alpha-1-adrenoceptor subtypes," Pharmacology, vol. 65, no. 2, pp. 69-73, 2002. 


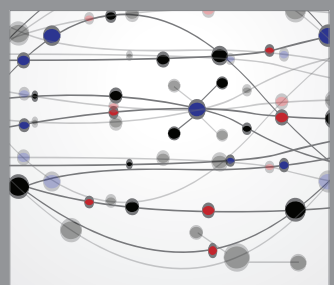

The Scientific World Journal
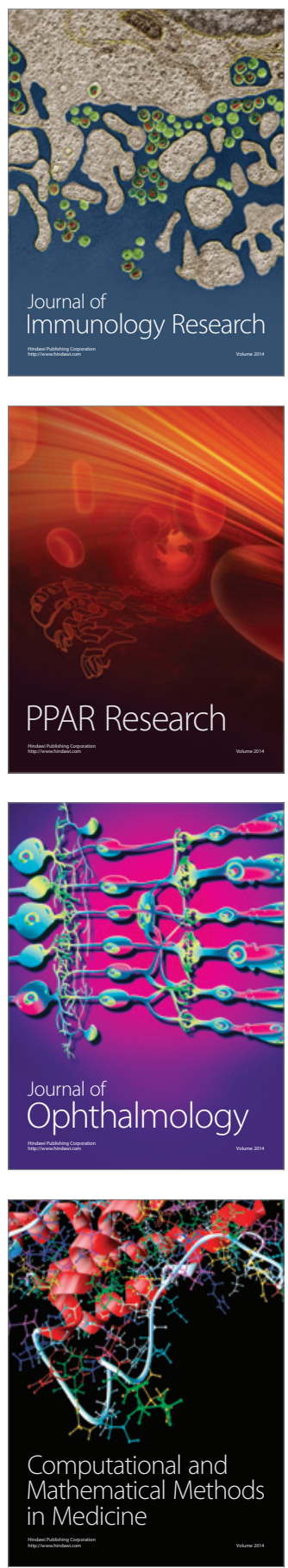

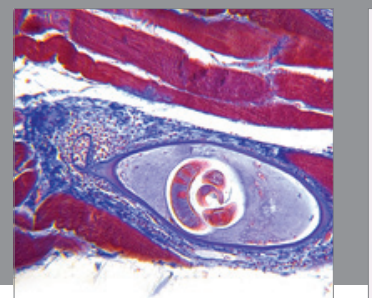

Gastroenterology

Research and Practice
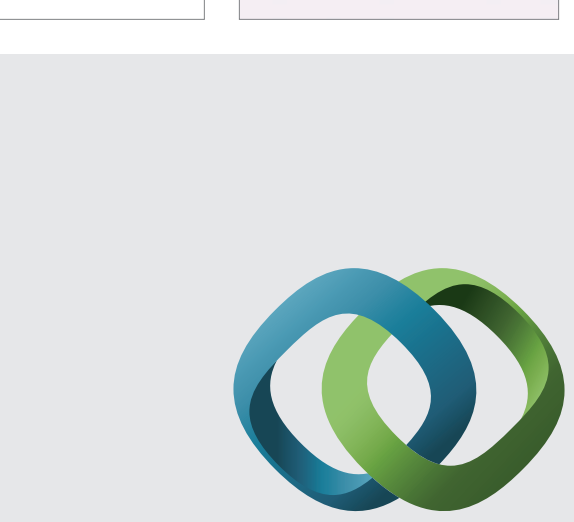

\section{Hindawi}

Submit your manuscripts at

http://www.hindawi.com
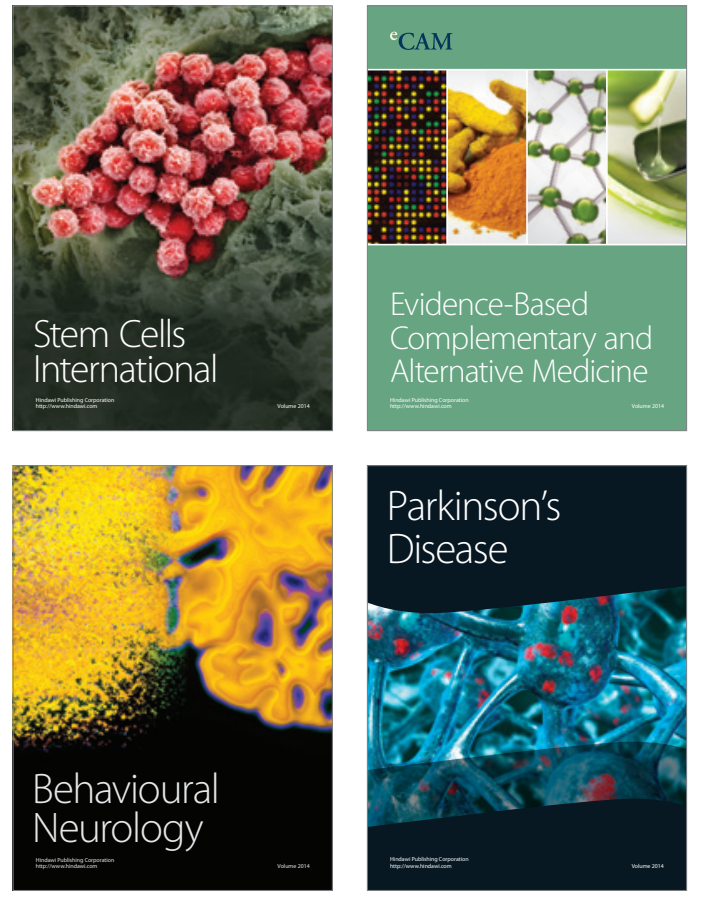
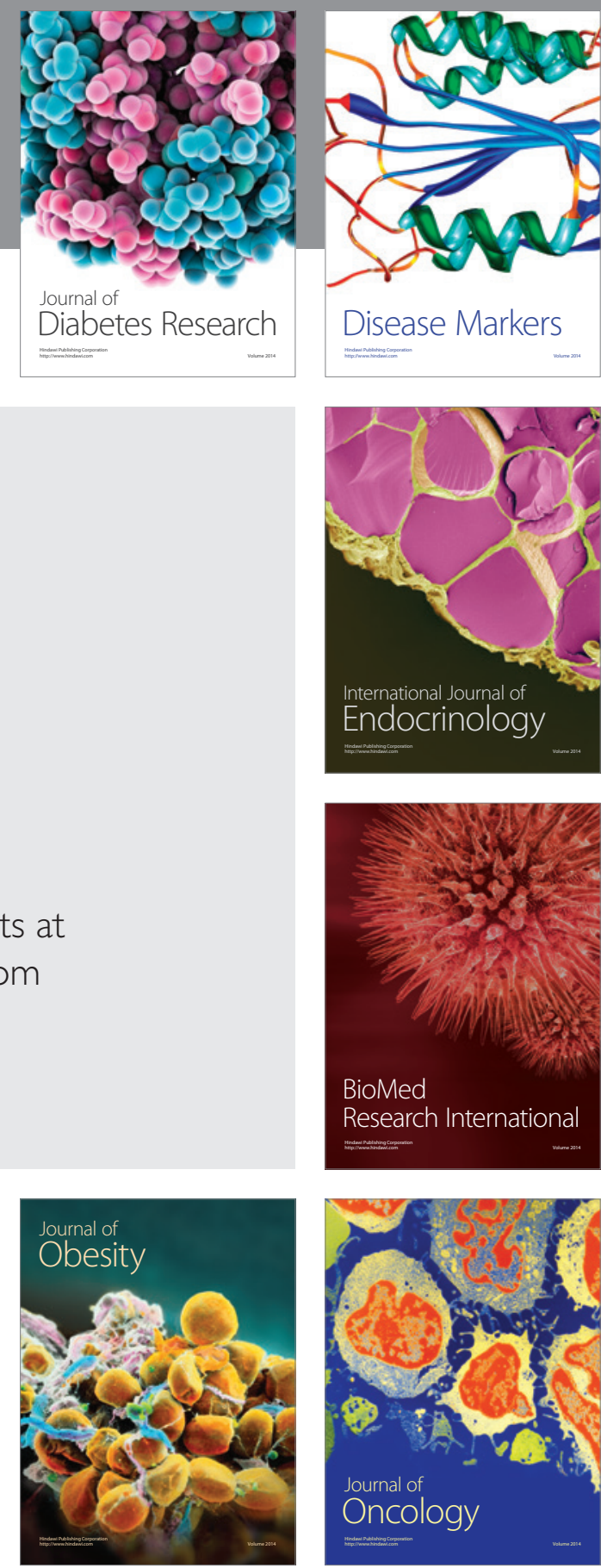

Disease Markers
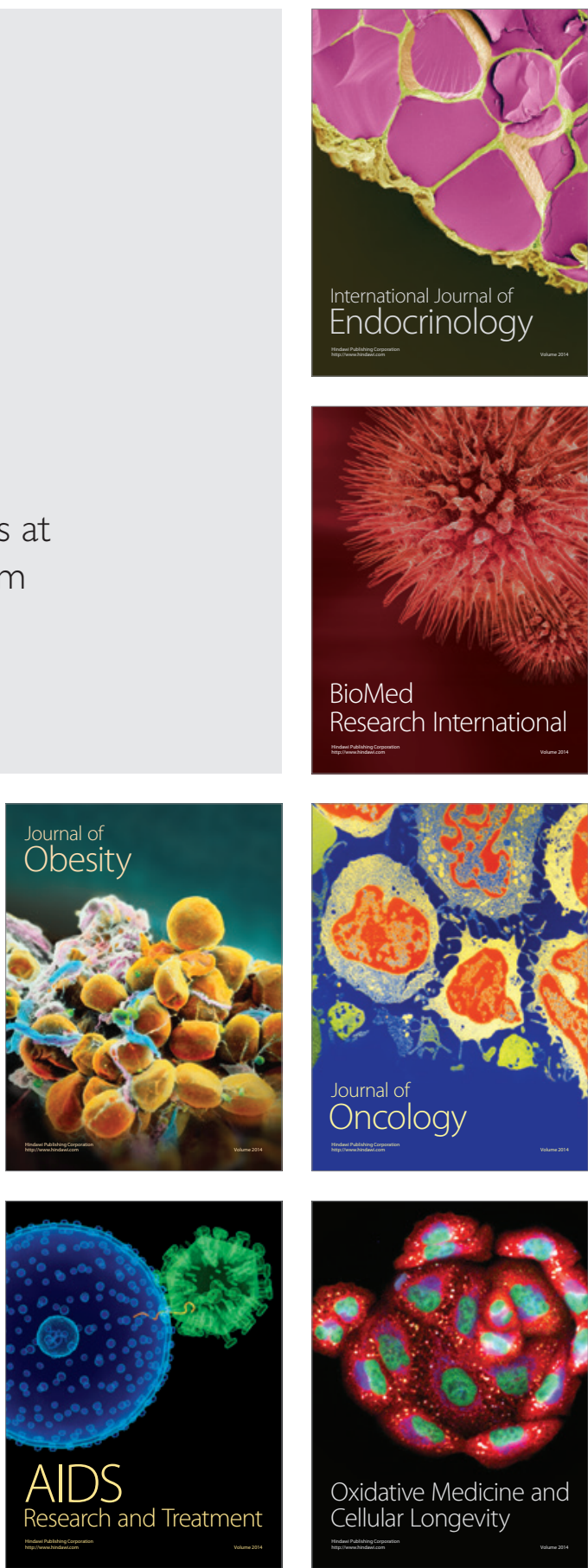